\title{
ANALYSIS THE APPROPRIATE USING STANDARD COSTING APPLYING IN LAND COST COMPONENT OF REAL ESTATE DEVELOPMENT ACTIVITIES: A CASE STUDY OF PT SUBUR AGUNG
}

\author{
Elfrida Yanti \\ Jurusan Akuntansi, Fakultas Ekonomi dan Bisnis, Bina Nusantara University \\ Jln. K.H. Syahdan No. 9, Kemanggisan, Palmerah, Jakarta Barat 11480
}

\begin{abstract}
Standard cost is generally used by manufacturing business, which direct material, labor, and factory overhead are cleared allocated. On real estate business in this case PT Subur Agung use standard cost based on three costs, raw land, land improvement and interest expense categories instead of direct material, direct labor and overhead. Developer use these cost to predict the project cost and estimate the pre-selling price, in accordance with the cost estimation classification matrix, the variance range is in the expected accuracy rate by testing the variance percentage between standard cost and actual cost. The additional similar projects in PT Subur Agung also follow the same scope. All these evidences have proved the appropriate using standard costing in land cost component of real estate development activities but how it applies this article will analyze in this particular project with using descriptive and exploratory method. The analysis started by knowing the conceptual situation of PT Subur Agung and the data was presented in tables and calculation with detail explanation.
\end{abstract}

Keywords: cost, business, developer, manufacture, project

\begin{abstract}
ABSTRAK
Biaya standar biasanya digunakan dalam bisnis manufaktur, yang material, tenaga kerja, dan pabriknya secara langsung teralokasi. Dalam bisnis real estate, dalam kasus ini seperti PT Subur Agung, menggunakan biaya standar berdasarkan tiga biaya, yaitu baku lahan, pengembangan lahan, dan kategori beban bunga; tidak hanya berdasarkan material langsung, tenaga kerja, dan overhead. Pihak pengembang menggunakan biaya-biaya tersebut untuk memprediksi biaya proyek dan estimasi harga pre-selling, dengan didasari oleh matriks klasifikasi estimasi biaya, variance range yang diekspektasikan nilai akurasi dengan mengecek persentase varian antara biaya standar dan biaya aktual. Proyek tambahan yang sama juga mengikuti cakupan yang sama. Semua hal membuktikan menggunakan pembiayaan standar di komponen harga lahan dari aktivitas pengembangan real estate, tetapi bagaimana mengaplikasikan artikel ini dengan menganalisis proyek menggunakan metode deskriptif dan eksploratori. Analisis ini dimulai dengan mengetahui situasi konseptual dari PT Subur Agung dan data dipresentasikan dalam tabel serta kalkulasi dengan penjelasan detil.
\end{abstract}

Kata kunci: biaya, bisnis, pengembang, manufaktur, proyek 


\section{INTRODUCTION}

Application of management accounting in companies is prime function, especially cost accounting. It because the efficiency of management relies on how effective it controls the cost. The research of Faas and Klaasse 1984, around 73\% of companies use historical costs for capital budgeting. While in their research of 1986, only 34\% of Dutch firms use historical cost for pricing decision-making. On the ongoing empirical studies to investigate costs and management accounting applications which use statistical surveys of different companies and company case-studies, when concentrating solely on new accounting approaches developed by the companies, it is found many evolution for companies' operational cost management accounting system which implemented a standard cost system. Standard costing here includes any statistical or non-accounting approach to variance analysis, where sometimes not all costs are covered.

The phenomena researcher try to explore is standard costing is not usual apply in the real estate development industry but in reality more than $50 \%$ using this method including PT Subur agung which is one of property developer company under ciputra group located in Jakarta, Indonesia. Standard costing is usually using in manufacturing industry, which suppose to display and calculate direct material, direct labor and factory overhead while in reality this cost are not applied by many real estate companies since most of the development activities are in contract externally.

Under standard costing, all costs are pre-determined and it then compared with the actual costs. The deference between this two cost is known as variance which is need to be analyzed and investigated and then reported to management for taking corrective action on the difference so that the actual cost mirror to predetermined costs. The problem with real estate development project is it takes quite long period for completion thus estimates price will really depend on predetermined cost. Real Estate Company may purchase a large tract of land to be developed over several years, some of the portion will be developed and sold partially before the project as a whole completed. In the normal practice, in order to finance the project developer would rely on pre-selling the houses. When preselling the house, it is quite difficult to know the real cost for each unit. In contrary, the company has to set up the pre-selling price to customer and not only that the method to record the inventory and cost of good sold is doubtful. Some other concerns from apply this method by these real estate companies the developer does not divide standard costs into three base costs (direct material, labor, overhead cost) and standard cost only depend on operation activities. This research concentrate how this project run with apply the unusual cost standard method for this type of industry.

By interviewing in a real estate development company group, namely, Ciputra group in Indonesia, who applies standard costing to make cost budged on all its project including project assigned on PT SUBUR AGUNG, this company started its commercial operation in 2004 for a project to develop it to be a shopping housing zone. The company's scope of activities is engaged in the development and sale of real estate, including office spaces, shopping centers and related facilities and industrial estates.

This research purposes are (1) to know how the company calculate the standard costing for land cost component; (2) to know how the company set-up the pre-selling price for each housing unit; (3) to know how the company using the standard costing to record in the financial statement, especially cost of goods sold in the whole project period; (4) to know how to revise and analysis the variance between standard cost and actual cost; (5) to test and analyze whether the standard costing is appropriate using in PT Subur Agung.

The advantages from this research are that (1) it could help educator and user of financial report to have knowledge how standard costing is used in the real estate development company in accordance with SFAS No. 44 and how its reconciliation between cost accounting and management 
accounting for standard cost in Real Estate Development Companies; (2) since this method is unusual applied for this industry, it could give comparison the advantages and disadvantages for using the standard costing; (3) by analyzing the variance, company can identify the problems and control the cost for effective and efficient management.

\section{RESEARCH METHODOLOGY}

\section{Analysis Method}

This research use exploratory and descriptive research method. Descriptive research method is used to describe the condition of company based on fact those facts will be processed, analyzed and interpreted. The information for this report is obtained from interviewing in this company. Meanwhile, exploratory method research gathers preliminary information that will help define problems and suggest hypotheses (Kotler et al, 2006). W. Lawrence Neuman (1997) explicated that exploratory research is used commonly when the issue being researched was new or researchers had written only little on it. Standard costing applied by real estate development it is not common thus the writer is trying to find the reasons why this method is used in few real estate development companies.

\section{Data Collection}

Data collection from two methods, library and field research. Library research is done by the learning theoretical literature. It can be in the form of books, article, journal, encyclopedia, dictionary, and others. Meanwhile, field research consists of primary data and secondary data. Those in primary data are research survey, observation and interview direct to the company which PT Subur Agung of Ciputra Group. The secondary data that have already been gathered by other researchers, data publish in journals, information available from any publisher or unpublished source and available in Internet. The secondary data in this researcher collected from PT Subur Agung in documentation format such as financial statement, standard cost for land and building, etc.

\section{Research Design}

Understand the conceptual information such as the Master plan, business plan and land acquisition process in PT Subur Agung of Ciputra Group. Understand the process and figure of how standard costing is used to calculate the standard cost for land cost budgeting. Explore how the developer use standard cost to determine the pre-selling price. Figure out how standard cost will be applied for land in inventory and cost of goods sold and also the effect on several items. When the actual cost recognized, how the developer should revise the variance and to test whether the variance deviation is significant or not.

\section{DISCUSSION}

PT Subur Agung started acquisition land since 1991 and acquired 20,572.2 square meters in total, which are not all the land can be used for constructing the building. Normally only $55-65 \%$ of land is used for infrastructure instead of buildings. Thus from 20,572.2 $\mathrm{m} 2$ only 7,611.71 m2 land available for sell and 12,960.49m2 for infrastructure. In business plan of the project developer make conceptual master plan consists of project background, master plan strategies, site planning framework and core area master plan, In this specific research, author chooses the first phase of the project which is 4,050 meter square land been used. The project construct for shopping house, which means owns 
shop stores in the downstairs, and house for living in the upstairs. Cost for land consists of purchasing for raw land cost, land improvement or development cost and interest expense for financing the project. However, land improvement is a long period of working process.

The developer budged the land improvement cost for the whole project, while the actual cost appears and is realized step by step. To realize the estimated cost in advance, the developer uses standard costing method to calculate the standard cost for this project. Unlike the normal standard costing for a product this project does not display structurally the cost items (direct material, direct labor and overhead) in the budgeting statement or use them as based but instead it used operation activities from their land improvement, raw land, and interest expense. Average price shown on table 4.3, raw land price per meter square in total is $\operatorname{Rp} 3,077,165(63,304,043,900 / 20,572.20)$ but average price land available for sale is $\mathrm{Rp} 8,316,661$ per meter square $(63,304.043,900 / 7,611.71)$. For land improvement the total cost is Rp.16,646,305,375 with detail items on table 4,2 the average price is Rp. 4,109,994 $(16,646,305,375 / 4,050)$ but price for the land available for sale, the price is Rp $11,108,093(16,646,305,375 / 1,498.5)$, the last cost is from interest expense, the total expense over the years (1998-2004) was 68,164,001,689 thus the average price is Rp. 3,313,404 (68,164,001,689/20,572.20) but interest expense from land available to sell the price become Rp $8,955,145$ meter square $(68,164,001,689 / 7,611.71)$ table 4.3 ,. as we can see the difference the price if the total land used and not. In the real estate development industry, the developer usually starts to sell the land before it is constructed completely, which calls pre-selling. This process could benefit the company to finance the operation.

Since the project has not been finished yet, the developer does not know the actual cost for the land. Since the project has not been finished, developer will set up the pre-selling price upon the percentage of standard cost. Standard cost it self acquired from 3 items (raw material, land improvement and interest expense) land available for sell, which is Rp. 28,379,899(8,316,661+ $11,108,093+8,995,145)$. On this project the pre-selling price set up for Rp 32,000,000 (12,7\% more than the standard cost) and the actual cost pr square is Rp 25,687,421 it means the pre-selling actually $24,5 \%$ higher. The impact of this overstated pre-selling price, will be on the financial recording since set up standard cost used for the whole project such as cost of good sold while the land in inventory is recorded in the actual cost every year thus the gross margin will increase It means the net income will also increase which cause increase in tax payment as one the consequences. The project started 2003 and started sold land on 2004 and 2005, by 2006 all the land available for sell sold out.

Table 1

\begin{tabular}{|c|c|c|c|c|c|}
\hline Item & & 2003 & 2004 & 2005 & 2006 \\
\hline Sales & & 0 & Rp. 5,632,000,000 & Rp 14, 592,000,000 & 0 \\
\hline Actual Cost & & 0 & Rp. 4,289,799,307 & Rp. $11,713,463,976$ & 0 \\
\hline $\begin{array}{l}\text { Actual } \\
\text { Margin }\end{array}$ & Gross & 0 & Rp. 1,342,200,693 & Rp. $2,878,536,030$ & 0 \\
\hline $\begin{array}{l}\text { Gross } \\
\text { Reported }\end{array}$ & Margin & 0 & Rp. $637,137,776$ & Rp. $1,650,766,060$ & 0 \\
\hline The differenc & & 0 & Rp. 705,065,917 & $1,227,769,970$ & 0 \\
\hline
\end{tabular}

The different between the actual gross margin and reported gross margin is quite big considered it is only some from the projects, the total difference has reached Rp. 1.932,832,887. The substances in actual cost are the same as when set up the standard cost the main different is on land improvement. Here, developer realizes the actual cost depends on a series transaction voucher, invoice, bank statement and journal entries. The main land improvement operation activity is from 1998 to 2002. Starting from 2003, the developer begins to construct the buildings, while the land improvement process is still on the process until 2005. 
Table 2

\begin{tabular}{ll}
\hline Realization of land improvement & Amount (RP) \\
\hline 1998 & $3,316,175,184$ \\
1999 & $381,188,646$ \\
2000 & $529,100,554$ \\
2001 & $1,720,920,450$ \\
2002 & $507,038,152$ \\
2003 & $1,857,442,714$ \\
2004 & $3,818,086,736$ \\
2005 & $480,846,835$ \\
\hline Total realization & $12,610,799,271$ \\
\hline
\end{tabular}

Source: Internal Memo of PT Subur Agung

Initially land improvement was Rp 16, 646,305,375 in total after realization it is only Rp. $12,610,799,271$ and as result the actual cost per meter square for land available for sale is Rp. $8,415,615$ (12,610,799,271/1,498.50). At the end phase of this project, the developer can statistics the data for standard cost and actual cost and compare the different variance.

Table 3

\begin{tabular}{lll}
\hline Land & Standard cost (Rp) & Actual cost (Rp) \\
\hline Raw Land & $63,304,043,900$ & $63,304,043,900$ \\
Land Improvement & $16,646,305,375$ & $12,610,799,271$ \\
Interest expense & $68,164,001,689$ & $68,164,001,689$ \\
\hline Total & $148,114,350,964$ & $144,078,844,860$ \\
\hline
\end{tabular}

Table 4

\begin{tabular}{lll}
\hline Land/m2 & Standard cost & Actual Cost \\
\hline Raw Land & $8,316,661$ & $8,316,661$ \\
Land Improvement & $11,108,093$ & $8,415,615$ \\
Interest expense & $8,955,145$ & $8,955,145$ \\
Total & $28,379,899$ & $25,687,421$ \\
Standard cost for land sold in $2004(176.00)$ & $4,994,862,224$ & \\
Standard cost for land sold in $2005(456.00)$ & $12,941,233,944$ & \\
\hline
\end{tabular}

At the end of this project, developer has to consider how to revise the overstated cost into the financials statement. It is impossible for the company to revise the financial statement for the previous years. Generally, the real estate accountant will put the variance into other incomes in the financial statement. The variance between standard cost and the actual cost journal as below:

Other Incomes Rp 4,035,506,100

Overstated Land cost Rp 4,035,506,100

Writer also interview other 20 projects regarding the accuracy of the cost estimation using variance formula below:

$\%$ of variance $=\underline{\text { standard cost } / \mathrm{m} 2-\text { Actual cost } / \mathrm{m} 2}$

$$
\text { Standard cost } / \mathrm{m} 2
$$

The result shown that the positive variation percentage ranges from $4.1 \%$ to $15 \%$, this is when standard cost higher than actual cost and the negative variation percentage range is from $-13.5 \%$ to $5.0 \%$, negative because actual cost higher than standard cost according to the cost estimate matrix, the 
standard variation is ranging from lowest $-10 \%$ to $-3.0 \%$ and the highest $3 \%$ to $15 \%$ it means all the static data from this 20 projects are in standard estimation scope.

Table 5 The Cost Estimate Matrix

\begin{tabular}{lllll}
\hline & $\begin{array}{l}\text { Primary } \\
\text { Characteristic }\end{array}$ & & Secondary Characteristic & \\
\hline $\begin{array}{l}\text { Estimate } \\
\text { Class }\end{array}$ & $\begin{array}{l}\text { Level of Project } \\
\text { Definition }\end{array}$ & End Usage & Methodology & $\begin{array}{l}\text { Expected Accuracy } \\
\text { Rate[a] }\end{array}$ \\
\hline Class 5 & $0 \%$ to $2 \%$ & Concept Screening & Parametric models & $\begin{array}{l}\text { L: }-20 \% \text { to }-50 \% \\
\text { H: }+30 \% \text { to }+100 \%\end{array}$ \\
Class 4 & $1 \%$ to $15 \%$ & Study of flexibility & Parametric models & $\begin{array}{l}\text { L: }-15 \% \text { to }-30 \% \\
\text { H: }+20 \% \text { to }+50 \%\end{array}$ \\
Class 3 & $10 \%$ to $40 \%$ & Budget or Control & Semi-detailed unit cost & $\begin{array}{l}\text { L: }-10 \% \text { to }-20 \% \\
\text { H: }+10 \% \text { to }+30 \%\end{array}$ \\
Class 2 & $30 \%$ to $70 \%$ & Control or Bid & Detailed unit cost & L: $-5 \%$ to $-15 \%$ \\
& & H: $+5 \%$ to $+20 \%$ \\
Class 1 & $50 \%$ to $100 \%$ & Check estimate or Bid & Detailed unit cost & L: $-3 \%$ to $-10 \%$ \\
& & & & H: $+3 \%$ to $+15 \%$ \\
\hline
\end{tabular}

\section{CONCLUSION}

It is appropriate to use standard costing applying in land cost components of real estate development activities in PT Subur Agung of ciputra because of conducted research and survey, comparison between historical cost and standard cost, applicable in accounting record practice, and in the scope of variance range for cost estimation.

\section{Conducted Research and Survey}

The application of historical cost for capital budgeting and pricing decision takes up $73 \%$ and $17 \%$ respectively. However, on 1988, the scientist conducts the research again and foundthat historical cost methods decreases to $15 \%$ and standard cost increases $60 \%$ from $0 \%$. It is also proved by survey of Cornick, Cooper and Wilson, that shows more than $85 \%$ of responding U.S companies use standard costs. All these facts evidence that standard cost is being used widely in the company practice.

\section{Comparison between Historical Cost and Standard Cost}

In the real estate development activities, different projects has different land, area, location, market, master plan, building coverage, plot ratio, public greening and so on. The magnitude of each of these cost components depends on the nature, size and location of the project as well as the management organization among many considerations. Historical cost is not applicable for these real estate development activities as the uncertain factors are too much for each project.

\section{Applicable in Accounting Record Practice}

Firstly, standard cost is quite easy to calculate the cost budgeting for the company. It is the starting point for company to make budgeting report. Secondly, it is benefit for setting up the prselling price since cost-based approach is used. Many risks are escaped by cost-based approach since the cost baseline is covered fully. Thirdly, even thought the company should revise the variance at the end of the period, write-off to cost of Goods Sold approach is also the simplest approach for dealing with the overstated of understated situation. 


\section{In the Scope of Variance Range for Cost Estimation}

Any cost estimation method would appear as the variance at the end of the project thus it would be standard costing. By testing the variance of PT Subur Agung. The variance percentage between standard cost and actual cost is $9.4 \%$, which is in the proper scope for cost estimation according to the cost estimation matrix.

\section{Recommendation}

\section{Company}

Standard costing is quite suitable to use and it is appropriate even though theoretically it is not usual for nature business like real estate business thus company should careful for any difference or mistake during the application because it will significant influence impact on a series of accounting cycles and also company management. For real estate company which is not using standard costing, writer suggests to reconstruct the accounting system to be able to apply standard costing.

\section{Public Associated Accounting Community}

The writer recommends that the public accounting standard setter (IAI) should conduct much deeper investigation about standard costing applying in real estate development activities. If possible, this community can regard standard costing as the common practice methods for land cost compaonent, especially for real estate development activities. Thus, it will be quite convenient for the external auditor to audit the financial reports of real estate development companies

\section{Future Research}

Future research could analyce about what other field that affected by this case. Therefore, the analysis of the data just not focuses on only land cost component but possibility on other side such as building cost component.

\section{REFERENCES}

Bhimani, A. (1996). Management accounting: European perspectives (7th ed.). New York: Oxford University Press.

Christensen, P., \& Burton, D. J. (2003). AACE International Recommended Practice. New York: McGraw-Hill.

Kinney, M. R., \& Railborn, C. A. (2005). Cost accounting: foundations and evolutions (2th ed.). New York: Pearson Education International.

Mnich, C. (2006). Introduction to SAP Real Estate Management. SAP AG. Retrieved May 7, 2010 from http://www.tacook.co.uk/media/pdf/00063_pre15.pdf

Newell, M. W. (2005). Preparing for the project management professional (PMP) Certification Exam (3th ed.). Boston: McGraw Hill.

Yin, R. K. (2003). Case study research (3rd ed.). Thousand Oaks, CA: Sage Publications. 